\title{
自律的な大学組織の相制関係に基づいた施設配置計画法 \\ LAYOUT PLANNING METHOD OF FACILITIES ESTIMATED BY AUTONOMOUS MUTUAL RELATIONSHIP AMONG ORGANIZATIONS IN UNIVERSITY
}

\author{
岩田 伸一郎*，宗 本 順 三** \\ Shinichiro IWATA and Junzo MUNEMOTO
}

\begin{abstract}
The relationship among organizations in university has a great influence over the layout planning of facilities in campus. It is difficult how to evaluate the entire plan. The effective way of it is to construct the whole in accordance with the factor which are close and easy to grasp. In Kyoto University, the layout pattern is searched from the mutual relationship among organizations which are treated as an agent having a space volume. By setting the degree of the mutual action, the density in 3D space is achieved, and thus the relation between parameters and the plan can be elaborated. By adjusting the parameters, the entire plan becomes easy to control and study.
\end{abstract}

Keywords: Layout planning of facilities, Organization in university, Multi Agent System, Autonomous decentralize

施設配置, 大学組織, マルチェージェントシステム, 自律分散

\section{1 研究の背累と目的}

多くの建物群からなる大学施設などの配置計画では、計画の初期 段階から全体の明確な目標や方向性を示すことができない場合が多 く、また、目標や方向性が建設プロセスを通して不変であることも 稀である。このような場合、建設プロセスの各段階で、その都度状 㫛に応じて最良と考えられる判断が行われるため、初期段階では絶 対的な評価の尺度をあえて設定しない方が好ましい。C・アレグザン ダーは、計画全体の明確な目標を定める近代の全体主義的な計画法 の限界を指摘し、部分同士が協調することで形成される全体の秩序 の重要性を、「全体性」*注という言葉を用い説明している。また、彼 は、そのような「全体性」は、個々の建設行為が互いに協調するこ とによって導かれるもので、全体に対する共通の理解は、各段階で 議論を重ねるフィードバックのプロセスによって次第に明確になる と述べている文 1,2)。

筆者らは、遺伝的アルゴリズムやニューラルネットワークを用い

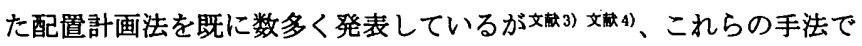
は演算過程で計画全体を評価する尺度が不可欠であり、計画全体の 目標を段階的にしか明確化することのできない問題に対して適用す ることは難しい。計画条件がますます複雑化し、多様な価值観が存 在する建築の問題にとって、計画全体を評価する尺度を設けること なく、それを段階的に形成しながら配置プランを導く計画手法を提
示することの意義は大きい。

大学キャンパスは様々な単位空間の集合と捉えられる。そこで、 「配置プランを構成する単位空間がお互いの条件を満たそうと制御し 合う関係 (以下、相制関係)」をモデル化することで、個別の計画条 件や計画者の目標（以下、計画ポリシー）に応じて全体と部分の機 能的な調和のとれた配置プランを導く計画法を考える。

計画全体の明確な計画ポリシーを示すことができない場合、計画 者は、部分の相制関係が満たすべき暫定的な目標を設定し、それに よって導かれる配置プランを経験的に評価することで、段階的に計 画ポリシーを具体化させる必要がある。計画ポリシーの変化に応じ て、部分の相制関係が満たすべき制約条件を調整したり、新たに追 加することで、協調的に配固プランを導くプロセスが有効であると 考える。

マルチェージェントシステムは、複数の行動主体（エージェント） が協カして全体の問題を解決する分散型システムである。各エー ジェントが個別の行動ルールや目標を持ち、個々が交涉しながら均 衡する状態を探索することによって高度で複雑な処理を可能とする。 エージェントが状況に応じて自律的に合併や分割などの再編を行う 特性は、多くの主体の意思によって成立する現実社会のモデルとし て応用されている。

本論では、計画全体を評価する明確な尺度が存在しない施設配直

* 京都大学大学院工学研究科 助手. 工博

** 京都大学大学院工学研究科 教授・工博

Inst., Graduate School of Engineering, Kyoto Univ., Dr. Eng.

Prof., Graduate School of Engineering, Kyoto Univ., Dr. Eng. 


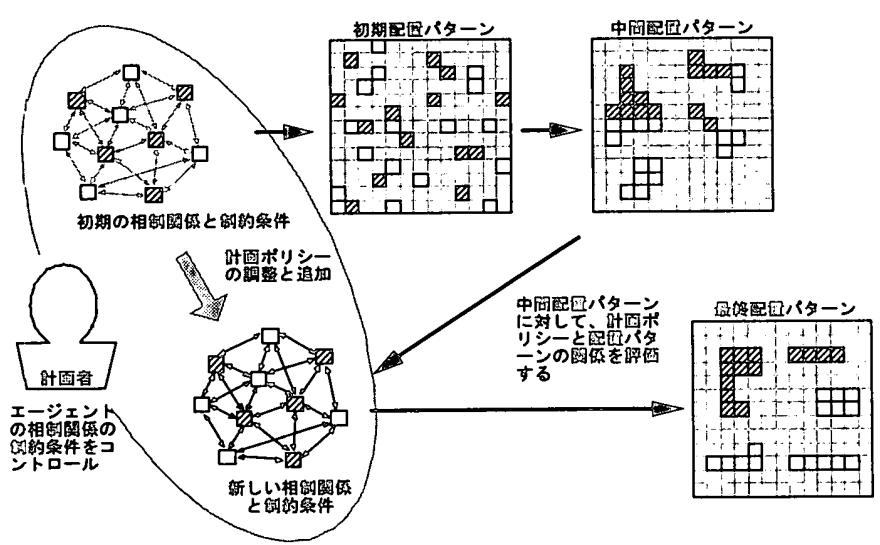

图1 マルチェージェントシステムを用いた協調型賥画プロセス

計画において、施設を構成する単位空間の相制関係をモデル化して マルチェージェントシステムの自己組織化機能を適用し、その相制 関係を調整することで段階的に計画を決定する協調型の施設配置計 画法を提案する。京都大学本部構内を事例として、複雑な組織同士 の関保や、保存建物、構内道路等の保持すべきキャンパスの骨格を 制約条件として持つときの施設配置を導く。大学組織は様々な研究 教育単位によって構成されており、しばしば個々の主体的な行動が 全体的な組織構成や施設配置に比べて重視される。そこで、大学の 各組織に属する単位空間をエージェントとして扱い、それぞれの エージェントに行動ルールと、周辺の他のエージェントとの関係に 関する制約条件とを与えることで、全てのエージェントが条件を満 たして安定する状態（以下、配固パターン）を探索させる。大学の 施設配置計画では、要求面積は要求条件として与えられるため、配 置パターンに関わらず容積率は一定となるが、建蔽率や建物分布の 密度には様々な配置パターンが考えられる。また、建物の規模や槽 数と共に、異種のエージェントの混在度も異なることが予想される ことから、エージェントの相制関係に対して与えられる計画ポリ シーが、配置パターンの特性に与える影響を考察する。

\section{2 本論の位置付け}

建築分野におけるマルチェージェントシステムの適用事例として、 藤井他による、複数主体の協調による作業効率などの推移のシミュ レーション文部 5.6 )や、藤岡他による、津波発生時の多種多様な人間行 動のモデル化による群集の避難シミュレーション女胡てがある。また、 瀧澤他は、土地利用の形成要因の解明を目的として、現実都市の土 地利用パターンを再現するモデルに応用している嚆8)。これらの既 往研究では、現実世界をよりリアルに再現するために、エージェン トの行動ルールやその条件は客観的で正確な情報に基づいて決定す ることが重要とされており、マルチェージェントシステムの本質的 な「問題構成要素の協調行動や動的な変遷過程を再現する機能」を 用いて問題のメカニズムを解明することが目的とされている。

本論は、エージェントに与える行動ルールとその制約条件を初期 段階では暫定的なものと位置付け、個別のエージェントが条件を充 足する特性と条件の容易な操作性に基づき、これらを段階的に調整 することで、計画全体を評価する尺度を定めることができない配置 問題に対する定常的な配置パターンの獲得を試みる点で独創的であ る。また、同じく評価の尺度が不明瞭な設計問題を扱い、その尺度
の獲得を目的とした設計プロセス論の分野における研究文藏9にに対し、 本論は、計画者が主体的に与える部分と全体の計画目標が満たされ た計画案の獾得を目的とした方法論として位固付けられ、他に䅡似 する研究はない。

3 マルチエージェントシステムによる施設配置モデル 3-1 配珇問題の条件

事例として取り上げた京都大学本部構内キャンパスは、第 2 種住 宅専用地域（容積率 $200 \%$ 、建 定されており、数地面積は $162,270 \mathrm{~m}^{2}$ 、現在の建築面積は 55,433 $\mathrm{m}^{2}$ (建蔽率 $34.2 \%$ )、総延床面積は $248,537 \mathrm{~m}^{2}$ （容䄼率 $153.2 \%$ ）で ある。近年、高度地区の特例が適用され、高さ $30 \mathrm{~m}$ 以下の建物まで 建設することが可能となっている。

施設の老朽化と狭险の改善が課題とされ、京都大学施設長期計画 書に従って施設の更新が行われてきた。しかし、新キャンパスの新 設に伴う工学研究科の大規模移転や組織の再編成といった大きな変 化が発生し、将来計画施設配置図の見直しが不可欠となっている。 従来の計画に基づいて既に建設された建物や歴史的価值の高い保存 建物を維持することを前提条件とした、新たな施設配置の将来ビ ジョンが求められる。本論の配置計画の対象は表 1 の通りである。

\section{竞1 配罢賥画の祄象となる面稳表}

\begin{tabular}{|c|c|c|c|}
\hline & 要求面償 $\left(\mathrm{m}^{\mathrm{n}}\right)$ & 瞅存面樌 (mi) & 対象面䆏 $\left(\mathrm{m}^{\prime}\right)$ \\
\hline 自然科学系ソーン(自然系) & 81,110 & 38,110 & 43,000 \\
\hline 人立科学系ソーン(人文系) & 86,070 & 21,910 & 64,160 \\
\hline 共用施段ソーン & $\begin{array}{r}52,480 \\
219660\end{array}$ & $\begin{array}{r}52,480 \\
112,500\end{array}$ & 107.160 \\
\hline & 219,660 & & 107,160 \\
\hline
\end{tabular}

\section{3-2 エージェントと配置空間の設定}

本論で設定するエージェントは、組織エージェントと環境エー ジェントに大別することができる（表 2)。組織エージェントは移動 可能なエージェントで、1 つのエージェントは 1 つの組織によって専 有される単位空間を表す。環境エージェントは固定されたエージェ ントであり、保存建物およびキャンパス周辺や構内道路として、組 織エージェントが活動する環境を形成する。

京都大学のほとんどの校舎は $7.5 \mathrm{~m}$ をモジュールとしており、奥行 きを 2 スパンとした中廊下型の建物が多い。1つのエージェントの平 面形状は、既存建物のモジュールに従って $7.5 \mathrm{~m} \times 7.5 \mathrm{~m}$ と設定する。

建物の最高高さを $30 \mathrm{~m}$ 以下となることを考慮し、1 1 エージェントの 高さを $10 \mathrm{~m}$ とし、同じ位膡に 1 つだけ配置されたときを「低層」、2 つ穦層されたときを「中層」、3つ積層されたときを「高層」と定義

亚2 エージェントの種類

\begin{tabular}{|c|c|c|c|c|}
\hline \multirow{2}{*}{ 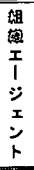 } & 自然系エージェント & $\begin{array}{l}\text { 低層 } \\
\text { 中層 } \\
\text { 离層 }\end{array}$ & St306 & \multirow{2}{*}{$\begin{array}{c}\text { 配酎対象 } \\
\text { 移動可 }\end{array}$} \\
\hline & 人文系エージェント & $\begin{array}{l}\text { 低層 } \\
\text { 中層 } \\
\text { 高層 }\end{array}$ & at 456 & \\
\hline \multirow{5}{*}{ 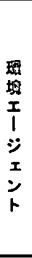 } & 保存㐁通エージェント & $\begin{array}{l}\text { 低層 } \\
\text { 中層 }\end{array}$ & & \multirow{5}{*}{ 移野不可 } \\
\hline & 保完自然系エージェント & $\begin{array}{l}\text { 中啳 } \\
\text { 高層 }\end{array}$ & & \\
\hline & 保存人文系エージェント & $\begin{array}{l}\text { 低層 } \\
\text { 中層 } \\
\text { 离層 }\end{array}$ & & \\
\hline & \multicolumn{2}{|l|}{ 推内道路エージェント } & & \\
\hline & キャンパス周辺エージェント & & & \\
\hline
\end{tabular}



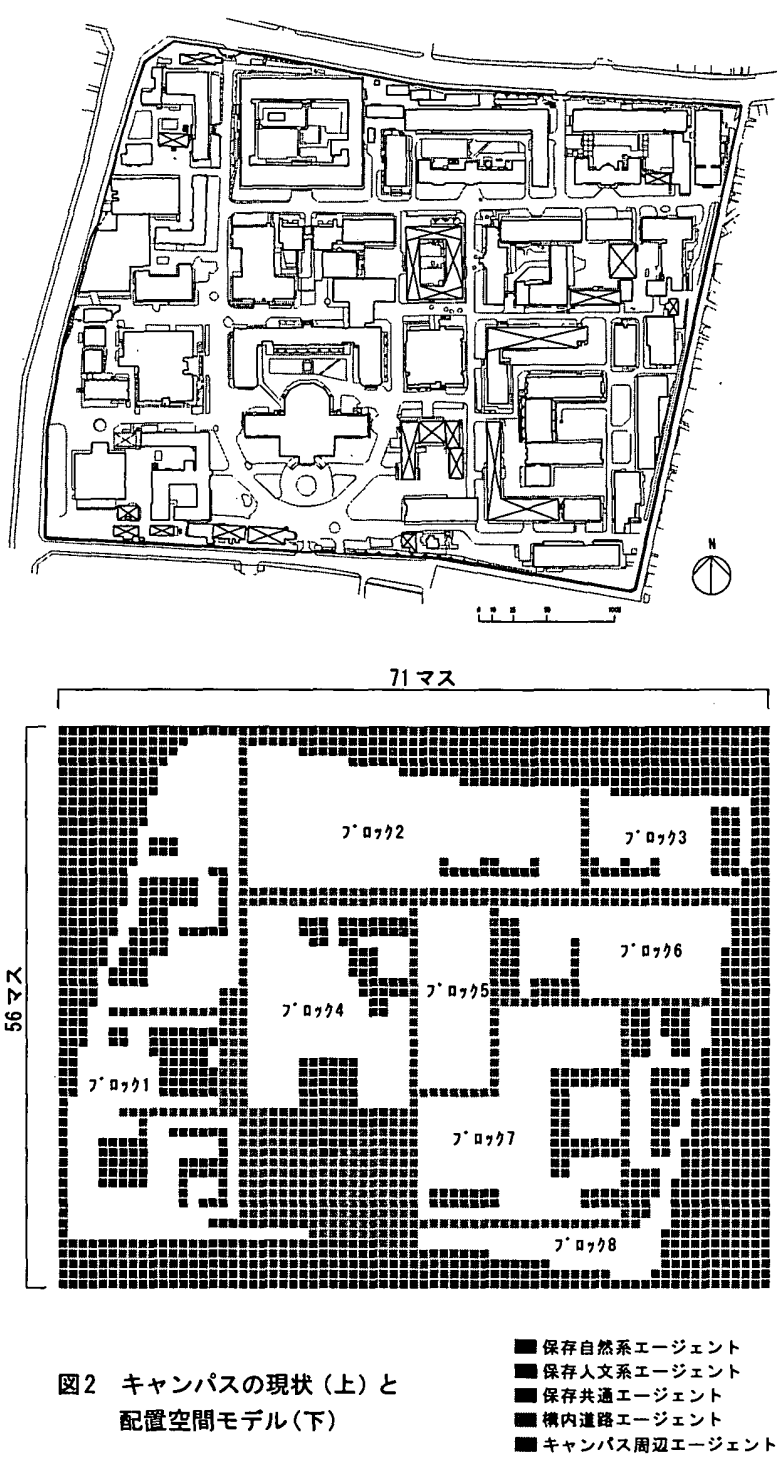

し、この 3 タイプの高さの建物によって、立体的なキャンパス空間 が構成されるものとする。

エージェントの配置空間として、図 2 に示す $71 \times 56$ マスの格子状 平面を用意する。これは現状のキャンパスの配置を簡略化したモデ ル空間である。1 マスはエージェント平面と同サイズの $7.5 \mathrm{~m} \times 7.5 \mathrm{~m}$ とし、初期状態において既に環境エージェントは配置されており、 組織エージェントを空白のセルにのみ配㯰することができる。低層 (GL) / 中層 $(+10 \mathrm{~m}) /$ 高層 $(+20 \mathrm{~m})$ の 3 層の配置空間を設け、 3 層の配置 空間におけるエージェントの配置によって、キャンパスの 3 次元的 な配置パターンを表現する。

\section{3-3 エージェントの相制関係の定義と行動ルール}

エージェントの相制関係を、指定された影響範囲内に存在する各 種エージェント数の組み合わせによって定義する。影響範囲の指定 方法を図 3 に示す。任意のエージェントの座標を（x,y) とし、この エージェントへの他のエージェントからの影響範囲を示すパラメー 夕を $\mathrm{k}$ とするとき、座標 $(i, j)[x-k \leqq i \leqq x+k, y-k \leqq j \leqq y+k]$ 上に 存在する他のエージェントの影響を受けるものとする。 $\mathrm{k}$ は、エー ジェントの種類によって決まる值であり、A と B の 2 種類のエージェ
ント間の影響力を考えるとき、A から B に対する影響範囲と B から A に対する影響範囲は区別する。

本論では概略的な空間配置を求めることを目的としていることか ら、上下方向の移動のための階段やエレベーターの配置に関しては 考慮していない。そのため、全ての平面座標において上下方向の移 動をスムーズに行うことができるものと仮定し、影響範囲は平面方 向にのみ設定している。

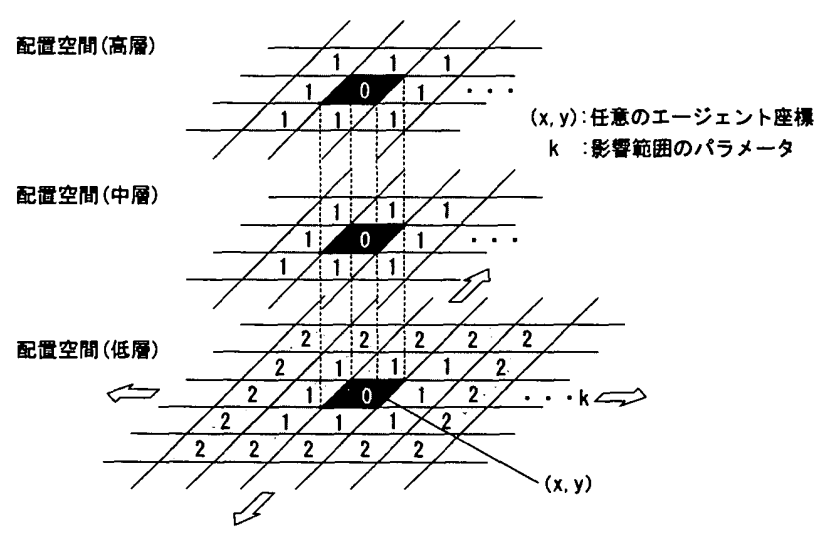

图3 影整範囲

エージェントごとに、そのエージェントの影響範囲内に存在する 他の各種エージェントの数の条件に応じた行動ルールを与える。一 つのエージェントの振る舞いは複数の動作ルールによって規定され、 他のエージェントの振る舞いによって動的に変化する環境下におい て、各エージェントは全ての条件を満たす安定した位置を探索する。 組織エージェント同士は同じ位置に重複して配置することが出来る ものとし、重複配置されたエージェントは、影響範囲の各種エー ジェントのまとまり度合の評価に基づいて、各層の配置空間に分配 される (表 3)。

表3 エージェントの重複と配置パターン

\begin{tabular}{|c|c|c|c|c|c|c|}
\hline \multicolumn{3}{|c|}{ 重䙡エージェント数 } & \multirow{2}{*}{$\begin{array}{c}\text { 配置パターン } \\
\text { 決定条件 }\end{array}$} & \multicolumn{3}{|c|}{ 配置パターン } \\
\hline 組棤 & 自然系 & 人文系 & & 低詹空間 & 中居空間 & 高層空间 \\
\hline \multirow[t]{2}{*}{1} & 1 & 0 & 無条件 & 自然系 & なし & な \\
\hline & 0 & 1 & 無条件 & 人文系 & なL & なし \\
\hline \multirow[t]{3}{*}{2} & 2 & 0 & 無条件 & 自然系 & 自然系 & な \\
\hline & 1 & 1 & $\begin{array}{l}\text { 2パターンから、まとまり } \\
\text { を比较してよい方を買択 }\end{array}$ & $\begin{array}{l}\text { 自然系 } \\
\text { 人文系 }\end{array}$ & $\begin{array}{l}\text { 人文系 } \\
\text { 自然系 }\end{array}$ & $\begin{array}{l}\text { なし } \\
\text { なし }\end{array}$ \\
\hline & 0 & 2 & 無条件 & 人文系 & 人文系 & な \\
\hline \multirow[t]{4}{*}{3} & 3 & 0 & 無㕛件 & 自然系 & 自然系 & 自然系 \\
\hline & 2 & 1 & $\begin{array}{l}\text { 3パターンか.らまとまり } \\
\text { を比較して最もよいもの } \\
\text { を選択 }\end{array}$ & $\begin{array}{l}\text { 自然系 } \\
\text { 自然系 } \\
\text { 人文系 }\end{array}$ & $\begin{array}{l}\text { 自然系 } \\
\text { 人文系 } \\
\text { 自然系 }\end{array}$ & $\begin{array}{l}\text { 人文系 } \\
\text { 自然系 } \\
\text { 自然系 }\end{array}$ \\
\hline & 1 & 2 & $\begin{array}{l}\text { 3パターンから,まとまり } \\
\text { を比較して最もよいもの } \\
\text { を買択 }\end{array}$ & $\begin{array}{l}\text { 自然系 } \\
\text { 人文系 } \\
\text { 人文系 }\end{array}$ & $\begin{array}{l}\text { 人文系 } \\
\text { 自然系 } \\
\text { 人文系 }\end{array}$ & $\begin{array}{l}\text { 人文系 } \\
\text { 人文系 } \\
\text { 自然系 }\end{array}$ \\
\hline & 0 & 3 & 無条件 & 人文系 & 人文系 & 人文系 \\
\hline
\end{tabular}

\section{3-4 変数とパラメータ}

各エージェントのまとまり度合やエージェントの相制関倸に関す る条件は、「隣接する各エージェントの数」と「影響範囲に存在する 各エージェントの数」の組み合わせとして表現することができる。 影響範囲内に存在可能な各種エージェントの数を変数とし、この変 数が満たさなくてはならない条件を与えることで、エージェントの 振る舞いをコントロールする（表 4)。全てのエージェントがこの表 
表4 変綮の一䜿

\begin{tabular}{|c|c|c|}
\hline $\begin{array}{l}\text { エージエント } \\
(x, y) \text { の変数 }\end{array}$ & 匙䇺範囲(k) & 内容 \\
\hline $\mathrm{s1}$ & 1 & 低層空間に存在する自然系エージエント数 \\
\hline S2 & 1 & 中啳空間に存在する自然系エージェント额 \\
\hline s3 & 1 & 高俤空間に存在する自然系エージェント數 \\
\hline S4 & 1 & 低層空間に存在する人立系エージェント額 \\
\hline S5 & 1 & 中柔空間に存在する人文系エージェント㩆 \\
\hline S6 & 1 & 㗐资空間に存在する人文系エージェント㪙 \\
\hline s7 & 1 & 保存共通 (低俤)エージェント改 \\
\hline 58 & 1 & 保存其通 (中俤)エージェント政 \\
\hline s9 & 1 & 保存自然系(中局)エージェント豍 \\
\hline s10 & 1 & 保存自然系(高局)エージェン卜鹳 \\
\hline S11 & 1 & 保存人文系(低俤)エージェント徵 \\
\hline S12 & 1 & 保存人文系(中桪)エージェント趾 \\
\hline $\mathrm{S} 13$ & 1 & 保存人文系(宫序)エージェント鼓 \\
\hline N1 & k1 & 低局空間に存在する自然系エージェント葆 \\
\hline N2 & k2 & 中居空間に存在する自然系エージェント路 \\
\hline N3 & k3 & 高䚄空間に存在する自然系エージェント數 \\
\hline N4 & k4 & 低桪空間に存在する人文系エージェント政 \\
\hline N5 & k5 & 中層空間に存在する人文系エージェント路 \\
\hline N6 & k6 & 蒿绝空間に存在する人文系エージェント效 \\
\hline N7 & k7 & 保存共通(低層)エージェント鳋 \\
\hline N8 & k8 & 保存共通 (中国)エージェント築 \\
\hline N9 & k9 & 保存自然系 (中層)エージェント數 \\
\hline N10 & $k 10$ & 保存自然系(高局)エージェント鿒 \\
\hline N11 & $k 11$ & 保存人文系(低屋)エージェント效 \\
\hline N12 & $k 12$ & 保存人文系(中局)エージェント衫 \\
\hline N13 & $\mathrm{k13}$ & 保疜人文系(高局)エージェント钘 \\
\hline N14 & $k 14$ & キャンパス周辺エージェントの做 \\
\hline N15 & $k 15$ & 欈内道路エージェントの數 \\
\hline N16 & k16 & エージェントを中心とした局部的なエリアの建蔽率 \\
\hline N17 & k17 & エージェントを中心とした局部的なエリアの容積率 \\
\hline N18 & なし & キャンパス全体の建蔽率 \\
\hline
\end{tabular}

※斯画条件より、敂地面程 2,877 マス、対象面稳 762 エージェント、保存䞨物 の延床面掼 494エージェントは变わらないので、容稳率も一定檤となる。

表5 共通ルール

\begin{tabular}{|c|c|c|}
\hline 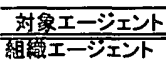 & 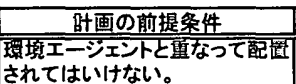 & 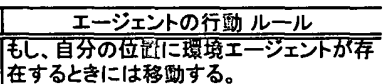 \\
\hline 組彎エージェント & 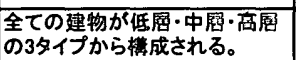 & 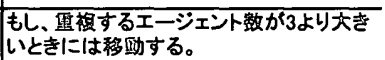 \\
\hline 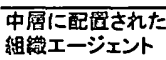 & ピロテイは考虜しない。 & 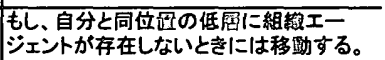 \\
\hline 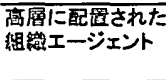 & $\begin{array}{l}\text { ピロティや中間外部層は恝膚し } \\
\text { ない。 }\end{array}$ & 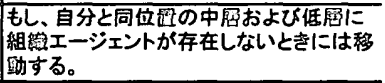 \\
\hline
\end{tabular}

4 にあげた変数を属性として持つわけではなく、問題ごとに、あるい はエージェントごとに、属性として持つ変数の組み合わせは異なる。

この他に、エージェントごとに機動力 $\mathrm{m}$ を設定する。座標 $(\mathrm{x}, \mathrm{y})$

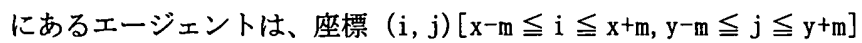
の中から、条件に対して最も適切な位置を探索して移動することが できる。

エージェントの行動ルールは、計画の目的に関わらず、エージェ ントが満たさなければならない共通配置ルール（表 5）と、目的ご とに独自に設定される個別配置ルール（表 6〜8）に分けられる。計 画者によって設定される、各変数が満たすべき条件やパラメータの 組みあわせによって示される個別配置ルールを、本モデルでは計画 ポリシーと考える。

3-5 マルチエージェントシステムのフロー

まず、表 2 の自然系エージェントと人文系エージェントを、低層 の配置空間に環境エージェントと重ならないようにランダムに配置 する。エージェントごとに、1 ステップごとに共通ルールと個別ルー ルを満たしているかを判定し、もし全ての条件を満たせば安定した

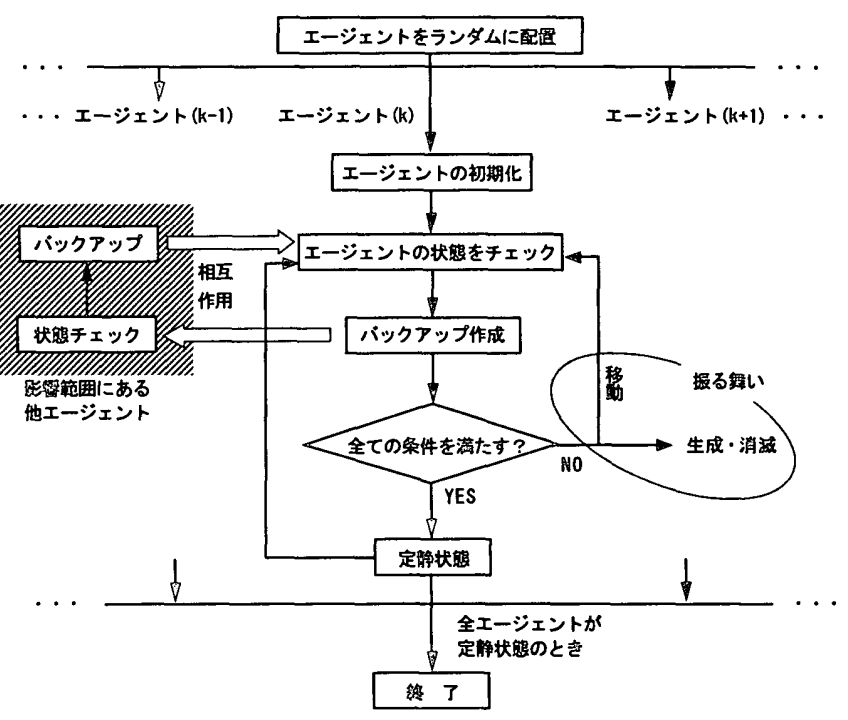

图4 システムのフロー

状態となり、条件を1つでも満たさない場合には、周囲のエージェ ントの状態に応じて移動する。

マルチェージェントシステムは、理論的には複数のエージェント が同時多発的に振る舞いを行うものであるが、コンピューターの演 算処理において、実際には1つ1つのエージェントの処理を順番に行 わざるを得ない。処理順序によって次のステップで読み込まれる状 態が異なるばかりか、実際にはありえない状態も発生してしまう。 ステップごとの振る舞いを厳密にコントロールする工夫として、状 態の一時的なバックアップを行う。各ステップにおいて、「1読み込 まれる前ステップの配置パターンの状態」に基づいて、「(2)個々の エージェントの変化後の状態」が求められ、そのデータがバック アップされる。全てのエージェントの処理が(1)に基づいて行われた 後、全てのエージェントに関する(2)のデータを同時に書き出し、(1) の更新を行う（図 4)。この操作によって、処理順序に左右されない 同時多発的なエージェントの振る舞いを再現することが可能となる。

各エージェントは、一旦、全ての条件を满たして安定した状態と なったとしても、他のエージェントの振る舞いによって条件が満た されなくなれば、再び移動を繰り返す。全てのエージェントは各ス テップごとに必ず 1 度評価され、全てのエージェントが安定した状 態となったとき、試行を終了する。

\section{4 シミュレーション}

事例として取り上げた京都大学の問題として、「異なる組織を混在 させない施設配置計画」と「複数組織の混在を許容した施設配置計 画」の 2 つの計画指針を想定する。これに基づいて計画ポリシーを 設定・調整することで、エージェントの相制関倸が良好に保たれた 配置パターンを求めるとともに、計画ポリシーと配置パターンの関 連性を分析する。

\section{4-1＼cjkstart巽なる組織を混在させない施設配笡計画（ケース 1）}

まず、従来の大学施設配置の一般的な考え方として、建物を単位 とし、1つの建物を 1 つの部局や学科といった組織に割り当てること で、建物ごとに使用組織を明確にする場合を考える。現状のキャン 
パスはこの考え方に基づいて形成されてきた。廊下・階段室・トイ レといった共有スペースを含めて、建物を単位で使用組織を特定す ることができるため、施設管理上の利点が大きいと考えられる。

このケースでは、まず各種エージェントの個別配置ルールを表 6 のように設定する。機動力は自然系・人文系ともに $\mathrm{m}=3$ とする。

上記の条件に対して導かれた配置パターン(ケース 1-1) を図 5 に示 す。キャンパス全体の建蔽率は $32.9 \%$ となり、簡単な条件式で規定 されたエージェント同士の相制関保から、1つの建物に異組織が混在 しない明確なゾーニングの行われた配置パターンが導かれた。人文 系エージェントの隣接に関する集合数の条件を小さく設定したこと から、小規模で多数棟の建物として分散配置されるか、低層の大規 模建物として配置されることが予想されたが、低層と中層おける建 物規模や分布密度は自然系と同程度となっている。これは自然系 エージェント数に対し人文系エージェントの数が約 1.5 倍存在する ため、個々のエージェントの関係性を弱く設定したとしても同程度 の密度とならざるを得ないためと考えられる。ただし、高層におけ る分布では、自然系エージェント数が人文系エージェント数を大き く上回る結果となっていることが特徵的である。

ブロック 4・ブロック $5 \cdot$ ブロック 7 では、エージェントの密度が 高く建て詰まり感が強い。キャンパス空間において建て詰まり感を 軽減することは、外部空間を評価する重要な指標の1つである。キャ
ンパス全体の建蔽率は $32.9 \%$ で現在のキャンパスと同等の值となっ ているものの、計画の要求面積は現状の延床面積に比べ $12 \%$ 少ない ことを考慮すると、優れた計画とは言えない。そこで、組織エージェ

表6 ケース1-1におけるエージェントの個別配置ルール

\begin{tabular}{|c|c|c|}
\hline 重エージェント & 8+画ポリシー & 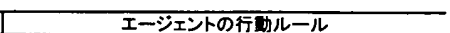 \\
\hline & 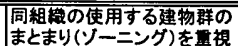 & 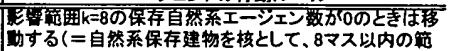 \\
\hline 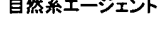 & & 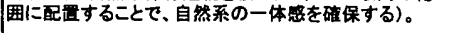 \\
\hline & & 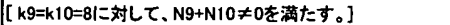 \\
\hline & 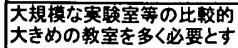 & 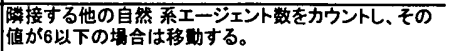 \\
\hline & & 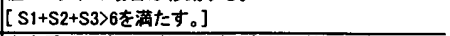 \\
\hline & 人文系との混在は特下問䏒 & 人文系エージエント数に関する尔件は特に即定しない。 \\
\hline & 原有建物之陵接しない。 & 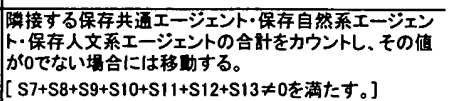 \\
\hline 人文系エーシ & 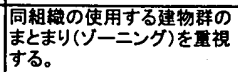 & 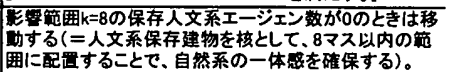 \\
\hline & & [ k11=k12=13=81対して、N11+N12+N13キ0を满たす。] \\
\hline & 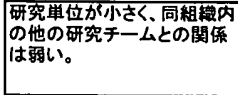 & 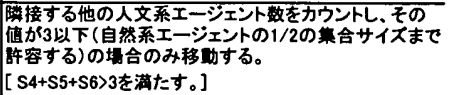 \\
\hline & 鿷・振的老考 & 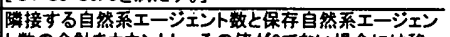 \\
\hline & & 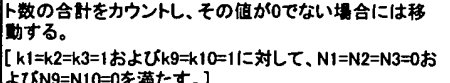 \\
\hline & 保存建物と睛接しない。 & 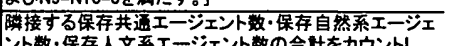 \\
\hline & & 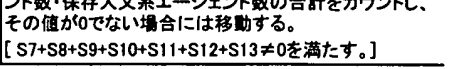 \\
\hline
\end{tabular}

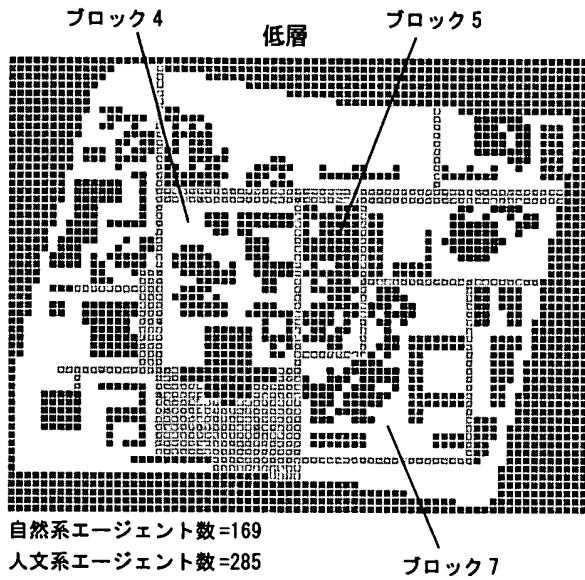

人文系エージェント数 $=285$

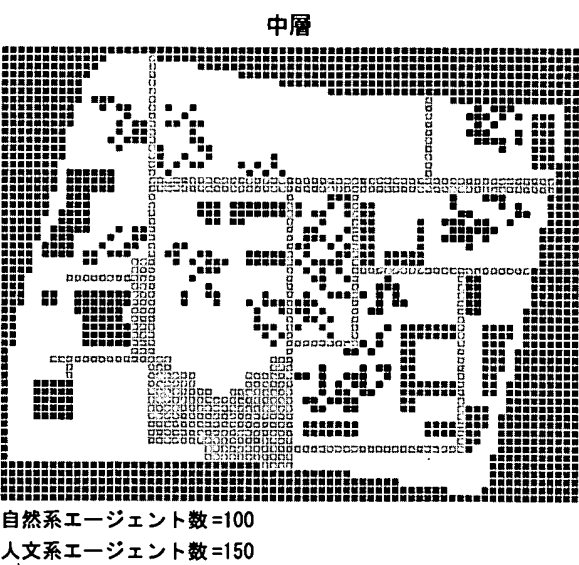

図5 ケース1-1の配㯰パターン (812ステップ)

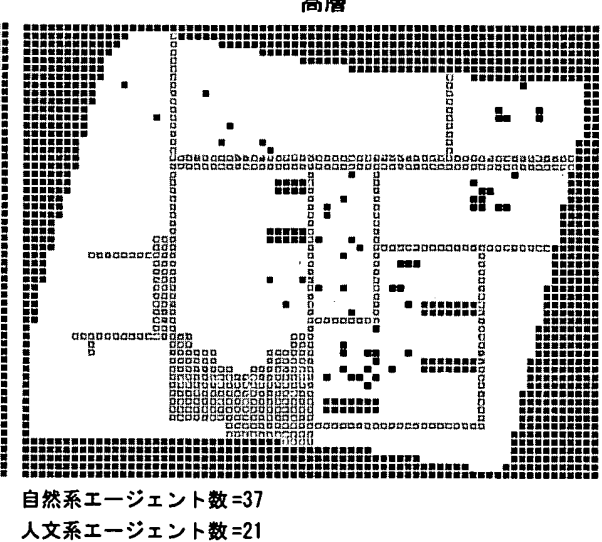

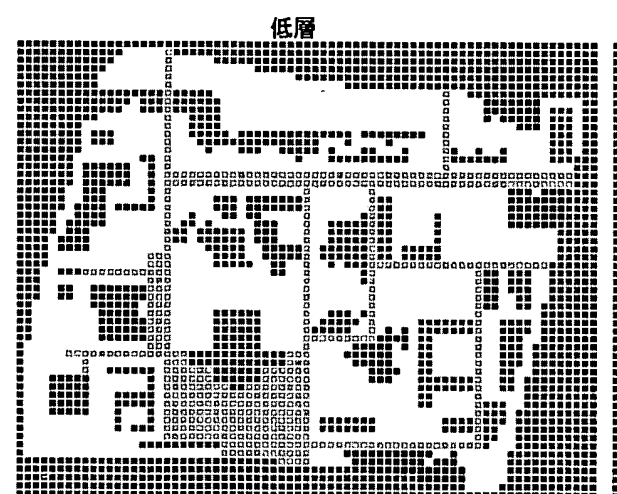

自然系エージェント数 $=137$

人文系エージェント数 $=188$

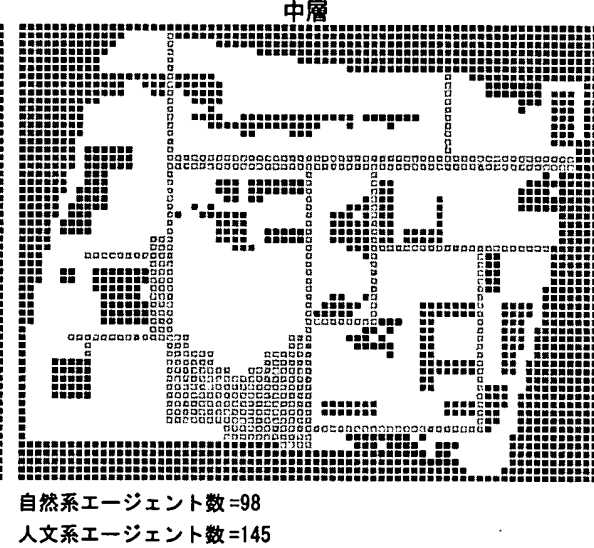

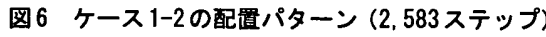

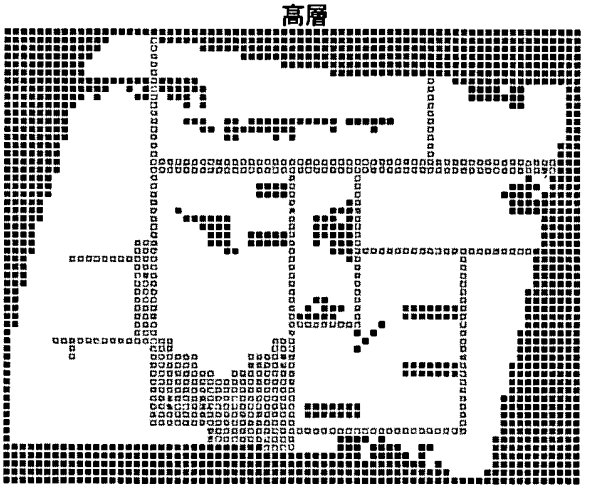

自然系エージェント数 $=71$ 人文系エージェント数 $=123$
自然系エージェント

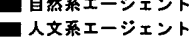

保存自然系エージェント

保存人䋆エージェント

保存共通エージェント

保存共通エージェント

日ャンノイス周㹦エージェント 
ントの満たすべき条件を見直し、新たにエージェントを中心とした 「ローカルなエリアの建蔽率」を検討する。

保存建物の建筑面樌はエージェント数にして 494 で、平均建物階 数は 4.1 階である。新築建物を全て 4 階建てと仮定するとキャンパ ス全体の建蔽率 $33.8 \%$ となり、また、全て 8 階建であると仮定する と $25.6 \%$ となる。この值を目安として、ローカル $(\mathrm{k} 16=10)$ な建蔽

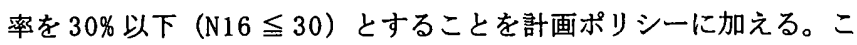
れによって導かれた配置パターン(ケース 1-2) を図6に示す。キャン パス全体の建蔽率は $28.5 \%$ となり、ケース 1-1 の結果と同様に明確 なソーニングが行われ、同じ建物内に異なる組織の混在は見られな い。新しく加えられた条件を満たすために配置パターンの調整が行 われており、ブロック 4・ブロック 5 ・ブロック 7 の局所的な建て詰 まり感が改善されている。組織エージェントの高さ方向の密度を比 較してみると、ケース 1-1では低層: 中層 : 高層=1:0.55:0.13 であったのに対し、ケース 1-2 では低層 : 中層 : 高層 $=1: 0.75: 0.60$ となっており、中層・高層の密度が増加している。また、建物が高 層化するだけではなく、各棟が明確に分棟される傾向も見受けられ る。

\section{4-2 複数組織の混在を許容した施設配置計画（ケース 2)}

ケース 1 に対し、建物を単位とする前提条件にとらわれない場合 の配置パターンを考える。近年の新たな研究領域の誕生や組織再編 成の変化に伴い、 1 建物に 1 組織を割り当てるという枠組みは崩れ、 1 つの建物を異なる組織によって使用されるケースが增えている。 先に述べたように、建物を単位とした施設配置は施設管理上の利点 が大きいが、配置パターンを考える上での大きな制約条件となって いる。ここでは、1 建物 1 組織の条件にとらわれず、組織エージェ ント同士の相制関係だけをより重視したときの、配置パターンの可 能性と異なる組織の混在度に関する傾向を調べる。

個別配県ルールとして表 7 を設定し、このルールによって導かれ た配置パターン (ケース 2-1) を図 7 に示す。自然系エージェントと 人文系エージェントの混在を制御する行動ルールは取り除いている が、同建物や同階における混在は起こっていない。同種類のエー ジェントの集合過程において、ある場所に小さな集合が生成される
と、他のエージェントは別の場所に集合して条件を満たすよりも既 にある集合に加わることで条件を満たそうする。その結果、条件と して与えた数値に対してより大きな集合が形成され易く、極端な分 散が発生しないと考えられる。人文系保存建物が配固されたブロッ ク 4 と自然系保存建物が多いブロック 6 ・ブロック 7 の中間に自然系 と人文系の複合建物が生成されており、周辺のエージェントの影響 を受けて建物内のソーニングが行われている。

次に、組織間の交流を誘発させることを意図して、2つの組織を積 極的に混在させる計画ポリシーを考える。また、大学キャンパスに おいて、建物の配置がキャンパス全体に均質的になりすぎると、 様々な生活のための場が生まれないため、適度な不均質さを形成す ることも考慮する。ケース 2-1 の配置パターンはやや均質的である ため、ローカルな建蔽率を算出するエリアを広げることで配置パ

$$
\text { 表7 ケース2-1におけるエージェントの個別配置ルール }
$$

\begin{tabular}{|c|c|c|}
\hline 対象エージェント & 跍画ポリシー & エージメントの行巭ルール \\
\hline \multirow[t]{5}{*}{ 自然系エージェント } & 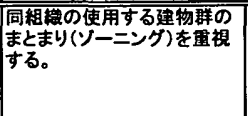 & 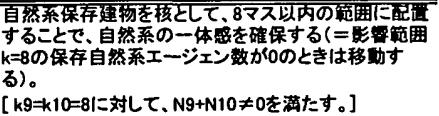 \\
\hline & $\begin{array}{l}\text { 大規模な荑駼室等の此較的 } \\
\text { 大きのの教公を多く偠とす } \\
\text { る。 }\end{array}$ & 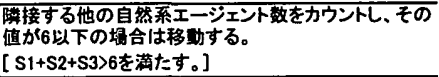 \\
\hline & 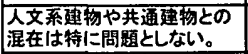 & $\begin{array}{l}\text { 人文系、保存人文系、保存共通エージェント数に関す } \\
\text { る㷛件は特に钤定しない。 }\end{array}$ \\
\hline & 保存建物之矔接しない。 & 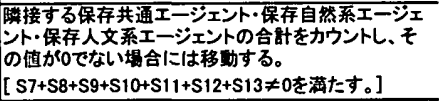 \\
\hline & 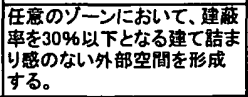 & 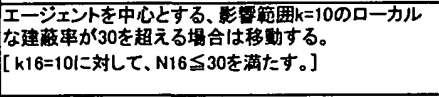 \\
\hline \multirow[t]{5}{*}{ 人文系エージェント } & 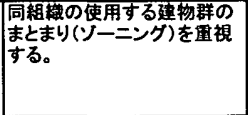 & 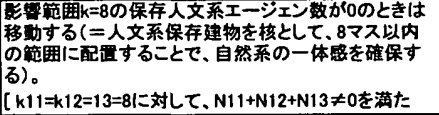 \\
\hline & $\begin{array}{l}\text { 研究単位が小さく、同組闇内 } \\
\text { の他の研究千ームムの関係 } \\
\text { は弱い。 }\end{array}$ & 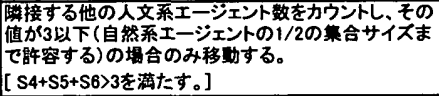 \\
\hline & $\begin{array}{l}\text { 百然系建物や其通建物との } \\
\text { 混在は特に問題としない。 }\end{array}$ & $\begin{array}{l}\text { 自然系、保军人文系、保存共通エージェント数に関す } \\
\text { る件は特に殷定しない。 }\end{array}$ \\
\hline & 保存建物と睛撞しない。 & 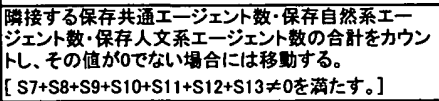 \\
\hline & 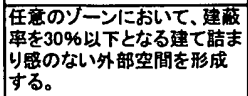 & 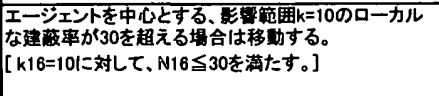 \\
\hline
\end{tabular}

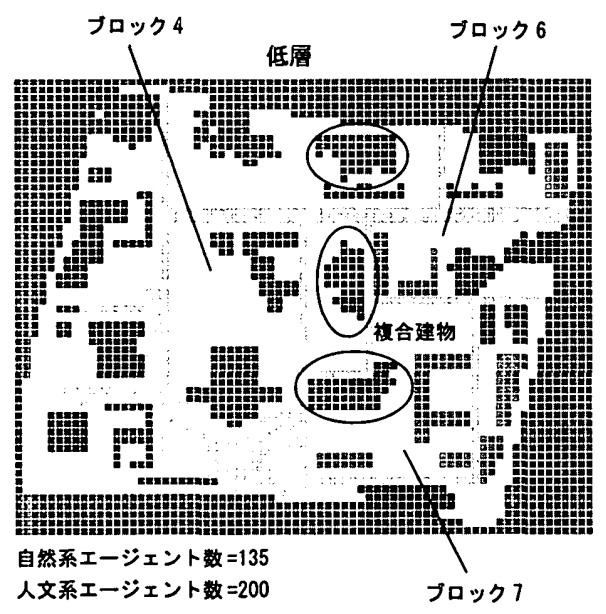

人文系エージェント数 $=200$

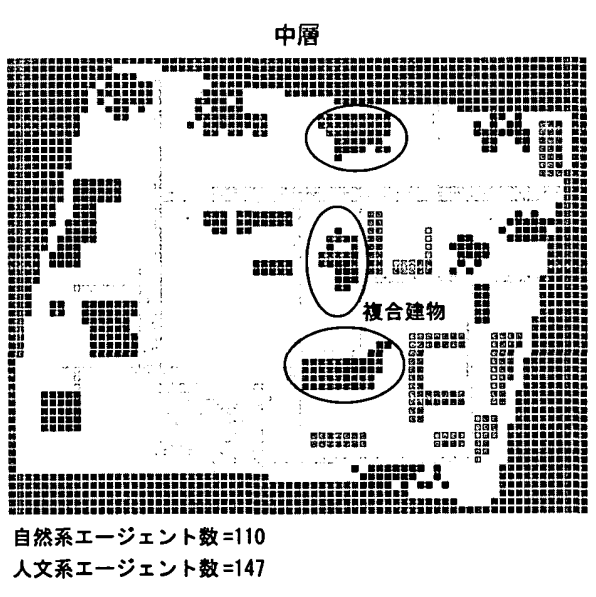

图 7 ケース2-1の配置パターン (1.437ステップ)

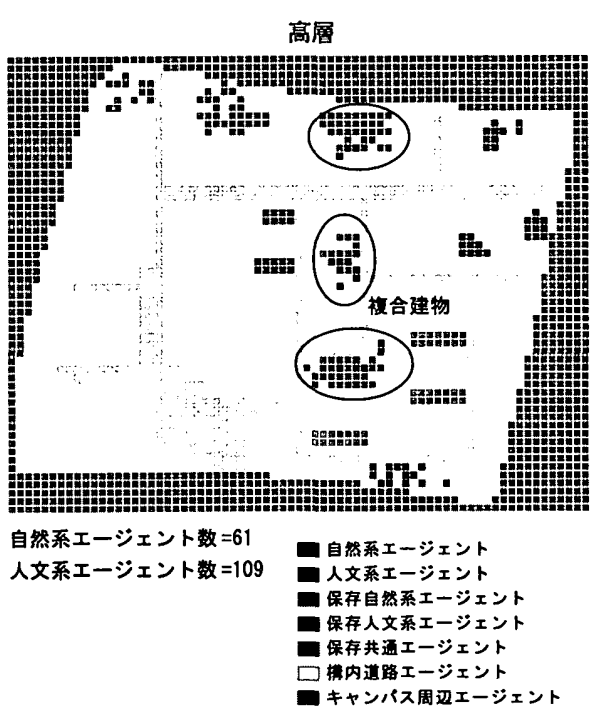


ターンの自由度を高める。さらに、大学建物がキャンパス周辺の環 境に圧迫感を与えないように配慮する。このときの個別配直ルール は表 8 のようになる。

上記の計画ポリシーに対して導かれた配置パターン（ケース 2-2) を図 8 に示す。自然系エージェントと人文系エージェントがよく混

表8 ケース2-2におけるエージェントの個別配置ルール

\begin{tabular}{|c|c|c|}
\hline 対象エージェント & 旪画ポリシー & $\begin{array}{c}\text { エージェントの行䖝ルール } \\
\end{array}$ \\
\hline \multirow[t]{7}{*}{ 自然系エージェント } & $\begin{array}{l}\text { 同相和の使用する建物群の } \\
\text { まとまりはあり重視しない } \\
\text { が、梗端な分散は群ける。 }\end{array}$ & 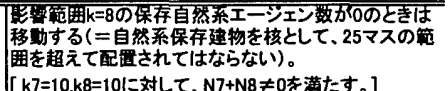 \\
\hline & 研究單位の坬立を避ける。 & 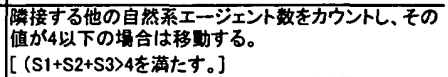 \\
\hline & 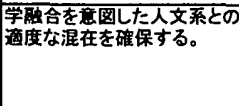 & 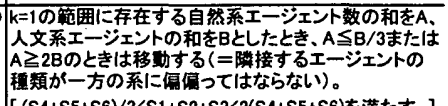 \\
\hline & & [ [ (S4+S5+S6)/3<S1+S2+S3<2(S4+S5+S6)を瀼たす。] \\
\hline & 保存建物と瀿接しない。 & 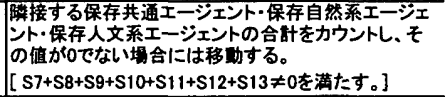 \\
\hline & 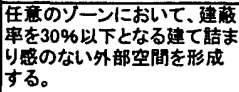 & 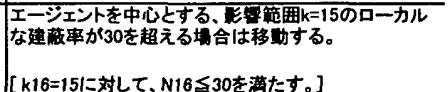 \\
\hline & 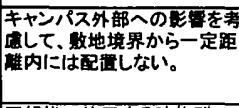 & 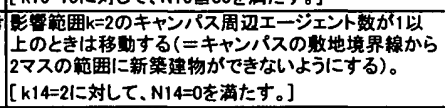 \\
\hline \multirow[t]{9}{*}{ 人文系エージェント } & 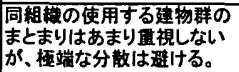 & 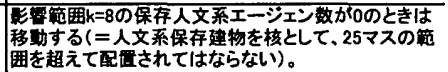 \\
\hline & & 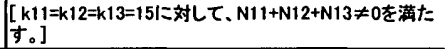 \\
\hline & $\begin{array}{l}\text { 学盟合を意图した自然系との } \\
\text { 通度な湦在を確保する。 }\end{array}$ & 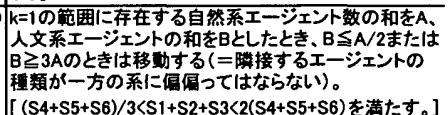 \\
\hline & 保存䖯物と洜接しない。 & 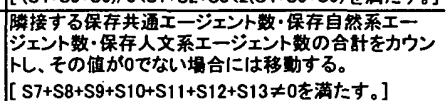 \\
\hline & 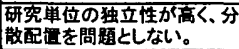 & まとまりに関する㷛件は特に設定しない。 \\
\hline & 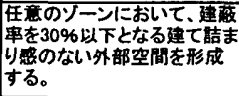 & 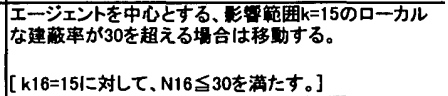 \\
\hline & $\begin{array}{l}\text { 共通建物の利用者が多いた } \\
\text { め、保存烡通建物への距噰 } \\
\text { を考的する。 }\end{array}$ & 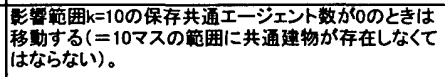 \\
\hline & & 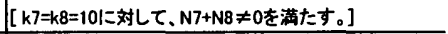 \\
\hline & 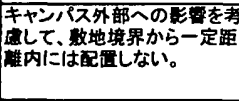 & 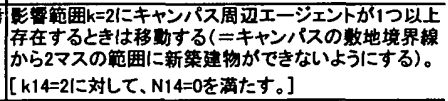 \\
\hline
\end{tabular}

ざり合った配置パターンなっており、中層・低層・高層の順に混在 度が高く、高層に配置されるエージェントのほとんどが人文系エー ジェントとなっている。ケース 2-1 の結果と比較すると、建物の棟 数が减少し、建物の平均規模が大きくなっていることがわかる。建 物の規模が大きくなることでキャンパス内に不均質さが生まれて、 複数のまとまったオープンスペースができたと考えら、計画ポリ シーに合致した配置パターンであると言える。
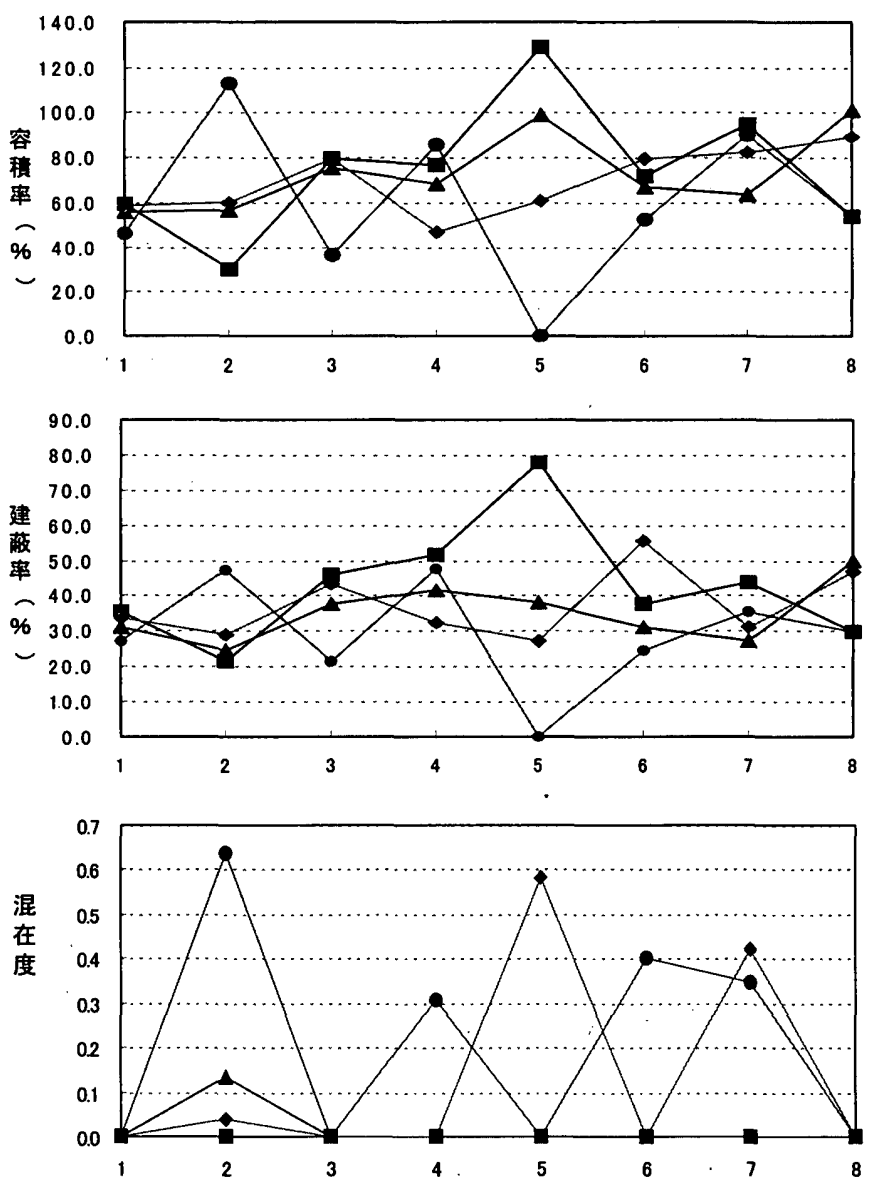

図9各ヶースにおけるブロック別の[建蔽率][容積率 $]$ [自然系・人文系混在度](横軸はブロックNo.)

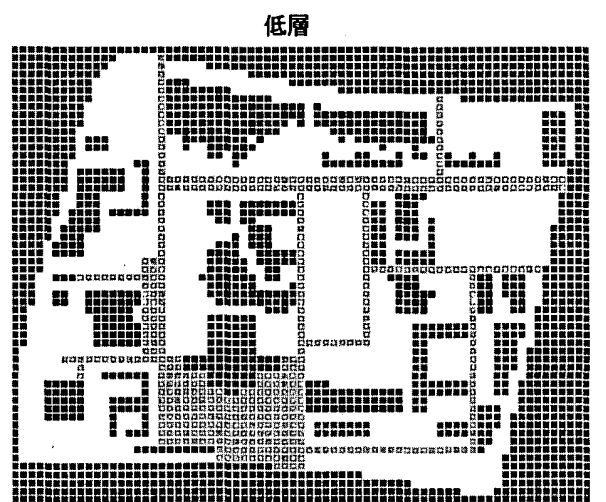

自然系エージェント数 $=119$

人文系エージェント数 $=199$

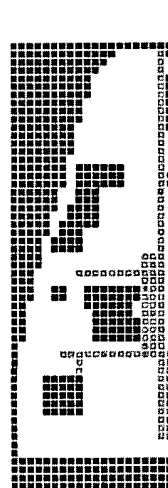

中莌

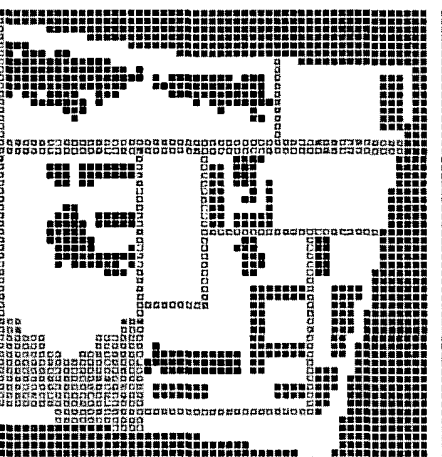

自然系エージェント数 $=152$

人文系エージェント数 $=103$

図8 ケース2-2の配置パターン $(2,182$ ステップ)

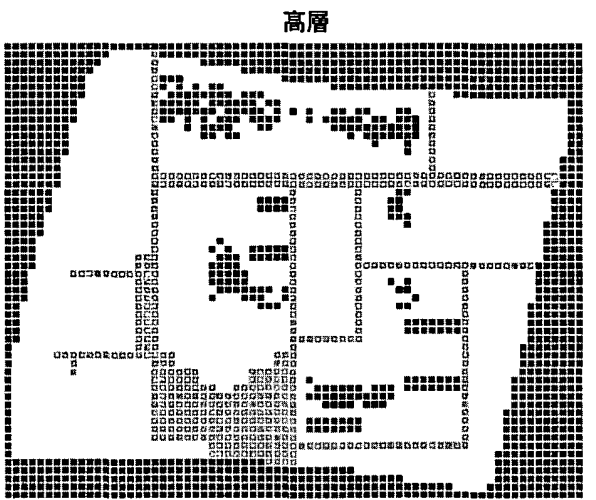

自然系エージェント数 $=35$ 人文系エージェント数 $=154$ 口人文系エージェント 保首自緐エージェント 保存人女系エージェント 保有半通エージェント 国满内迹路エージェント もキャンバス周辺エージェント 


\section{5 配置計画手法としての有効性に関する考察}

様々な配置パターンの検討を行うためには、あらかじめ行動ルー ルと実際のエージェントの振る舞いの大要を把握しておくことが必 要である。本論の各ケースの結果は、行動ルールの設定の試行錯誤 の末に導かれたが、そこで得られた変数の条件とパラメータの設定 のテクニカル的な知見を以下に記す。

（1）エージェントの集合数に関する条件

大規模なエージェントの集合が形成される過程では、まず小規模 な集合が多数生成され、これを核として他のエージェントが取り込 まれながら成長し、条件に適合する集合だけが淘汰されてさらに成 長を続ける。エージェントが安定するための集合数の条件として大 きな值を設定すると、核となる小規模の集合が発生しにくくなって しまう。エージェントの集合数に関するルールを与えるとき、核と なる小規模の集合の生成を調整することが重要となる。本論では、 核の最小集合数条件を、「0」個から「4」個の 5 段階に調整すること で、建物と見なすのに十分に多様な規模や形態の集合が発生するこ とを確認した。また、それ以上に大きな值を設定すると、急激に核 の生成および安定が困難になった。

（2）影響範囲

N1 から N18（表 4）の変数の制約条件を設定するには、同時に決定 される影響範囲 $\mathrm{k}$ の值との関倸を考慮する必要がある。 $\mathrm{k}$ の值が小さ いとき、変数の変化量に対する配置パターンの変化は大きく、 $\mathrm{k}$ の値 が大きいとき、同じ変数の変化量に対して配置パターンの変化は小 さくなる。ローカルな建蔽率やソーニングといった、広域に関する 配置ルールを操作するためには、影響範囲 $\mathrm{k}$ の值と相対的に変数の 調整幅を大きくすることが必要となる。本論のシミュレーションで は、 $\mathrm{k}=10$ のときの適切な変数の調整幅を「3」としている。

（3）初期状態

同じ配置ルールを用いた場合の配置パターンの再現性を確認する ことは、手法としての有効性を示す上で重要である。シミュレー ションの準備段階の試行錯誤において、初期状態を発生させる乱数 を変化させたときの配置パターンの傾向を検証している。収束過程 では、核となる集合の数、大きさ、位置の異なるタイプの配置パター ンが出現した。しかし、一度形成された集合が、まだ安定した状態 に至っていないェージェントの影響を受けて再び分解され、新たな 集合場所を探索を繰り返すことで、最終的には、建物の位置や形状 にある程度のばらつきや違いがあるものの、おおよそ同様の傾向を 示すと言える配置パターンが得られることを確認した。ただし、安 定するまでのステップ数は、初期状態に依存して大きな差が出る結 果となった。

(4) 機動力

配置パターンの連続的な変化にとって、エージェントの機動力の 設定は重要である。保存建物や構内道路の配置がェージェントの移 動を拘束する方向に働くため、適度に大きな機動力が必要となる。 しかし、機動力が大きすぎるとき、まだ条件を満たさずに移動する エージェントが、条件を満たして安定しているエージェントの集合 を分解する頻度が高くなり、ステップごとの演算時間も飛躍的に増 大する。効率的な配置パターンの探索にとって、適度に緩やかな変 化の実現が不可欠であり、エージェントの適度な機動力は、まず自 らの近傍において安定可能な位置を探索し、必要に応じて広域を探
索することを意味する。本論では、構内道路の最も大きな幅員に基 づいて機動力を「3」と設定している。

特定の配置ルールの変更が配置パターン及ぼす影響を厳密に記述 することは難しいとはいえ、上記のようなテクニカル的な知見は、 相制関係が満たすべき制約条件を設定する上で有用な情報である。

\section{6 まとめ}

本論では、初期段階において計画の明確な方向性を定めることが 困難な問題に対する計画法に関する考察を行った。施設を構成する 単位空間の相制関係をモデル化し、その相制関係の制約条件を調整 することで、段階的に計画全体の目標を決定して配置パターンを導 く配固計画法を提案した。また、このような協調型の計画法に対し て、マルチェージェントシステムを応用することの有効性を示した。

この計画法では、計画者による調整は必ずェージェントの相制関 係に関する条件に対して行われるため、獲得された配置プランは、 部分において計画者の計画ポリシーを必ず満たすものとなる。また、 最終的な配置プランは、計画者の知識や経験に基づいて総合的な視 点からも評価されることで、部分の条件だけを満たす断片の寄せ集 めではなく、部分と全体の秩序が計画者によってバランスよく調整 された価值の高い情報となる。

「全体性を作り出す仕事は、都市がかたちを形成していくプロセス が根本的に変わった時、初めて可能になる就り」というC・アレグザ ンダーの言葉を引用すれば、マルチエージェントシステムと計画者 の協調型プロセスのよって、多様な価值観が存在する配置計画に対 して、部分と全体のバランスの取れた配置プランを導くための一つ の方法論を示すことができたと言える。

注釈

全体性 (Wholeness)：全体が部分を規定していくという「全体主義」的ニュアンス とは区別される。この概念は、ある実体が下からみれば全体であり、上から見れば 部分であり、自己主張と統合がバランスを保っている状態をいう文就1。

\section{参考文献}

1) C・アレグザンダー他 : まちづくりの新しい理論, 鹿島出版会

2) C・アレグザンダー他: オレゴン大学の実験, 鹿島出版会

3) 岩田伸一郎, 宗本順三, 吉田 哲, 阪野明文:移動コストを評価関数とした室配 置人のGA適用と発想支援一「An approach to the optimum layout of singlestorey buildings」における病院手術棟を事例として一，日本建築学会計画系 論文集 No. 519 pp. 341-347, 1999.5

4)岩田伸一郎, 水沼靖昭, 宗本順三:大学の組織構成要素のまとまりと要求面穔充 足度に基ついた既存校舎への室再配置計画、日本建築学会計画系論文集 N0. 565 pp. $167-173,2003.3$

5）谷本潤，藤井晴行 : 複雑系モデルに基つくアカテミック・ソサエティの盛衰予 測に関する研究一大学における研究組織と効率に関する考察一, 日本建築学会計 画系論文集 N0. 559 pp. 299-306, 2002.9

6) 藤井晴行, 谷本潤:社会システムとしての学術組織のエージェントに基つくく ミュレーション, 日本建築学会計画系論文集 N0. 561 pp. 189-196, 2002.11

7) 藤岡正樹, 石橋健一，楃秀樹，场越功 : 津波避難対策のマルチエージェントモ デルによる評価, 日本建築学会計画系論文集 N0. 562 pp231-236, 2002. 12

8) 瀧澤重志, 河村廣, 谷明勲: 適応的マルチエージェントシステムによる都市の土 地利用パターンの形成, 日本建築学会計画系論文集 N0. 528 pp. 267-275, 2000.2

9）松下大輔、宗本順三: 対話型進化計算による形態構成规則の獲得モテル，日本 建筑学会計画系論文集 N0.560 pp. 135-142, 2002.10

10) 山影進, 服部正太 編: コンピュータのなかの人工社会ーマルチェージェント シミュレーションモデルと複雑系ー, 共立出版

(2003年 2 月 10 日原稿受理，2003年 7 月 23 日採用決定) 